INFO ARTIKEL

Riwayat Artikel:

Diterima : 05 Mei 2018

Disetujui : 22 Agustus 2018

GEOGRAFI

\title{
KERUSAKAN LINGKUNGAN AKIBAT INDUSTRI BATU BATA DI DESA PANGKALAN BENTENG SEBAGAI SUMBER PEMBELAJARAN ILMU PENGETAHUAN SOSIAL (GEOGRAFI) DI MTS GUPPI SUKAMORO
}

\author{
Supriyadi $^{1}$, Helfa Septinar ${ }^{2}$ \\ ${ }^{1-2}$ Program Studi Pendidikan Geografi Universitas PGRI Palembang \\ (凹) helfa23@yahoo.com ${ }^{2}$
}

\begin{abstract}
ABSTRAK
Industri Batu Bata adalah industri yang memanfaatkan tanah sebagai bahan baku dan memberikan akibat negatif terhadap lingkungan. Kerusakan lingkungan akibat Industri Batu Bata dapat dijadikan sumber belajar. Rumusan masalah penelitian ini adalah bagaimana kerusakan lingkungan akibat industri Batu Bata di Desa Pangkalan Benteng sebagai sumber pembelajaran ilmu pengetahuan sosial (Geografi) di MTs GUPPI Sukamoro. Tujuan penelitian ini untuk mengetahui dan menggambarkan kerusakan lingkungan akibat industri Batu Bata di Desa Pangkalan Benteng sebagai sumber pembelajaran ilmu pengetahuan sosial (Geografi) di MTs GUPPI Sukamoro. Metode yang digunakan yaitu deskriptif kualitatif. Penelitian ini dilakukan Desa Pangkalan Benteng. Teknik analisis data dalam penelitian ini menggunakan reduksi data, penyajian data dan kesimpulan. Hasil penelitian menunjukan bahwa di Desa Pangkalan Benteng terdapat 400 industri Batu Bata yang memberikan pengaruh positif dan negatif. Pengaruh positifnya adalah sebagai penyerapan tenaga kerja, sumber mata pencaharian dan daya beli masyarakat meningkat. Sedangkan pengaruh negatifnya berpengaruh terhadap kerusakan lingkungan fisik yang meliputi banyaknya lubang bekas galian, merusak kualitas dan kuantitas tanah, menurunnya kualitas air, pencemaran udara dan kerusakan akses jalan. Sehingga kerusakan lingkungan akibat Industri Batu Bata di Desa Pangkalan Benteng dapat dijadikan sumber pembelajaran di MTs GUPPI Sukamoro.
\end{abstract}

Kata kunci: Kerusakan Lingkungan, Industri Batu Bata, Sumber Belajar

\section{PENDAHULUAN}

Pendidikan adalah usaha sadar yang dilakukan oleh keluarga, masyarakat, dan pemerintah, melalui kegiatan bimbingan, pengajaran, dan latihan yang berlangsung di sekolah dan di luar sekolah sepanjang hayat, untuk mempersiapkan peserta didik agar dapat memainkan peranan dalam berbagai lingkungan hidup secara tepat di masa yang akan datang (Mudyahardjo, 2001:11). Pendidikan berlangsung pada semua lingkungan hidup, baik yang khusus diciptakan untuk kepentingan pendidikan atau pendidikan formal maupun yang ada dengan sendirinya sebagai pengalaman belajar dalam hidup atau non formal.

Pentingnya sumber belajar dalam kegiatan pembelajaran tidak bisa dipungkiri lagi. Akan tetapi sumber belajar yang ada di sekolah atau lembaga pendidikan lainnya selama ini, umumnya belum dikelola dan dimanfaatkan secara maksimal. Menurut Yusuf (dalam Prastowo, 2012:2) sumber 
belajar adalah segala jenis media, benda, data, fakta, ide, orang, dan lain-lain yang dapat mempermudah terjadinya proses belajar bagi peserta didik. Adapun contohnya seperti buku paket, modul, LKS, RPP, maket, museum, dan sebagainya. Tujuan pemanfaatan teknologi pembelajaran adalah untuk berusaha merancang, mengembangkan, mengorganisasikan dan memanfaatkan berbagai sumber belajar sehingga dapat mempermudah proses pembelajaran peserta didik.

Belajar menurut Miarso (dalam Abdullah, 2012:217) merupakan suatu kegiatan baik dengan bimbingan tenaga pengajar maupun dengan usahanya sendiri. Kehadiran pendidik dalam proses pembelajaran bertujuan agar belajar lebih lancar, lebih mudah, lebih menyenangkan, dan lebih sukses, sedangkan bagi peserta didik belajar pada dasarnya untuk memperoleh pengetahuan, keterampilan, dan dapat mengembangkan potensi dirinya di mana saja, kapan saja, dan dengan apa saja, sebab sumber belajar terdapat di mana saja dan ada beragam jenisnya.

Salah satu yang dapat dijadikan sumber belajar adalah kerusakan lingkungan akibat industri Batu Bata. Industri Batu Bata sangat bergantung pada ketersediaan bahan baku utamanya yaitu tanah. Menurut Wijayanti (2012:44) Batu Bata sering disebut juga dengan Batu Bata merah, ukuran Batu Bata di berbagai tempat dan daerah tidaklah sama besarnya, hal tersebut diakibatkan karena belum adanya keseragaman ukuran dan teknik pengolahan Batu Bata. Industri Batu Bata memiliki akibat baik itu bersifat positif dan bersifat negatif. Akibat positif industri Batu Bata lebih mengarah pada penyerapan tenaga kerja, pendapatan penduduk dan daya beli masyarakat, sedangkan akibat negatif industri Batu Bata lebih banyak berakibat pada kerusakan lingkungan, meliputi kerusakan tanah, air, udara dan akses jalan. Kerusakan lingkungan akibat industri Batu Bata yang akan dapat digunakan sebagai sumber belajar khususnya industri Batu Bata yang berada di Desa Pangkalan Benteng Kecamatan Talang Kelapa Kabupaten Banyuasin yang merupakan sentra produksi Batu Bata yang cukup dikenal di wilayah Sumatera Selatan. Berdasarkan data pemerintah desa, tercatat ada 400 bangsal Batu Bata di wilayah desa Pangkalan Benteng.(website Kabupaten Banyuasin)
Objek studi kerusakan lingkungan akibat industri Batu Bata dapat dijadikan sebagai sumber belajar dalam pembelajaran ilmu pengetahuan sosial di MTs Guppi Sukamoro karena peneliti menemukan permasalahan dalam kegiatan pembelajaran IPS Terpadu, yaitu belum dimanfaatkannya sumber belajar lokal. Dimana pada pembelajaran ilmu pengetahuan sosial (geografi) banyak materi yang dapat dikaitkan dengan lingkungan alam sekitar salah satunya terdapat materi tentang permasalahan lingkungan hidup khususnya mengenai bentuk-bentuk kerusakan lingkungan hidup dan faktor penyebabnya.

Berdasarkan observasi awal peneliti banyak kerusakan lingkungan yang disebabkan Industri Batu Bata mulai dari tahap awal sampai tahap akhir pembuatan Batu Bata. Karena peneliti melihat belum tersedianya penggunaan sumber belajar kerusakan lingkungan akibat industri Batu Bata yang terdapat wilayahnya sendiri dan agar siswa dapat mengetahui berbagai kerusakan lingkungan yang ada di sekitarnya dan memberikan pemahaman mengenai pendidikan. Oleh karena itu peneliti mengharapkan dengan adanya sumber belajar kerusakan lingkungan akibat Industri Batu Bata ini dapat membantu siswa mengingkatkan pemahaman dengan penyajian data lebih menarik.

Berdasarkan informasi dan observasi awal tentang industri Batu Bata. Maka peneliti merumuskan judul dalam penelitian ini yaitu "Kerusakan Lingkungan Akibat Industri Batu Bata di Desa Pangkalan Benteng Sebagai Sumber Pembelajaran Ilmu Pengetahuan Sosial (Geografi) di MTs Guppi Sukamoro".

\section{METODOLOGI PENELITIAN}

Menurut Yunus (2010:423), metode penelitian merupakan dasar-dasar kerangka penelitian diletakan. Dalam penelitian ini metode yang digunakan adalah metode penelitian kualitatif dengan pendekatan deskriptif kualitatif, yaitu untuk menggambarkan keadaan atau fenomena serta untuk mengetahui hal-hal yang berhubungan dengan data yang dikumpulkan dan fakta-fakta yang ditemukan di lapangan. 
Menurut Arikunto (2010:3) penelitian deskriptif adalah penelitian yang dimaksudkan untuk menyelidiki keadaan, kondisi, atau hal-hal lain yang sudah disebutkan yang hasilnya dipaparkan dalam bentuk laporan penelitian Penggunaan metode ini bertujuan untuk mengetahui kerusakan lingkungan akibat industri Batu Bata di Desa Pangkalan Benteng sebagai sumber pembelajaran ilmu pengetahuan sosial (geografi) di MTs Guppi Sukamoro, sesuai dengan data yang dikumpulkan dan fakta-fakta yang ditemukan di lapangan.

Untuk menunjang penelitian, maka data yang digunakan peneliti adalah data berupa data kualitatif. Sumber data adalah subjek dari mana data dapat diperoleh (Arikunto, 2014:22). Sumber data dapat dibedakan menjadi dua:

1) Sumber data primer adalah sumber data yang secara langsung memberikan data kepada pengumpul data (Sugiyono, 2015:308). Sumber data primer diperoleh langsung dari informan (sumber informasi). Penentuan informan dalam penelitian ini dilakukan dengan teknik purposive sampling, yaitu memilih informan pertimbangan khusus yaitu informan yang akan dipilih adalah masyarakat di desa Pangkalan Benteng dan guru mata pelajaran IPS di MTs Guppi Sukamoro.

2) Sumber data sekunder adalah data yang diperoleh dari dokumen-dokumen grafis (tabel, catatan, notulen rapat, SMS, dan lain-lain), fotofoto, film, rekaman video, benda-benda dan lainlain yang dapat memperkaya data primer (Arikunto, 2014:22).

Teknik pengumpulan data merupakan langkah yang paling utama dalam penelitian, karena tujuan utama dari penelitian adalah mendapatkan data. Tanpa mengetahui teknik pengumpulan data, maka peneliti akan mendapatkan data yang memenuhi standar data yang ditetapkan (Sugiyono, 2015:308).

Menurut Riduwan (2015:76), observasi yaitu melakukan pengamatan secara langsung ke objek penelitian untuk melihat dari dekat kegiatan yang dilakukan. Apabila objek bersifat perilaku dan tindakan manusia, fenomena alam (kejadiankejadian yang ada di alam sekitar), proses kerja dan penggunaan responden kecil. Pada penelitian ini teknik observasi dilaksanakan dalam langkah mengumpulkan data primer dengan cara melakukan pengamatan langsung di lapangan untuk mendapatkan data tentang keadaan dampak lingkungan yang disebabkan Industri Batu Bata di desa Pangkalan Benteng dan MTs Guppi Sukamoro.

Dokumentasi merupakan catatan peristiwa yang sudah berlaku. Dokumen bisa berbentuk tulisan, gambar, atau karya-karya monumental dari seseorang (Sugiyono, 2015:329). Adapun dokumentasi yang dilakukan dalam penelitian ini adalah dokumentasi yang berasal dari instansi terkait berupa catatan, laporan, foto atau gambar, peta, tabel, serta informasi-informasi yang diperlukan dan ada kaitannya dengan permasalahan yang akan diteliti.

Wawancara adalah metode pengambilan data dengan cara menanyakan sesuatu kepada seseorang yang menjadi informan atau responden (Afifuddin \& Saebani, 2012:131). Adapun wawancara yang akan digunakan peneliti dalam memperoleh data adalah wawancara tidak berstruktur. Wawancara tidak berstruktur adalah wawancara yang bebas dimana peneliti tidak menggunakan pedoman wawancara yang telah tersusun secara sistematis dan lengkap untuk mengumpulkan datanya (Sugiyono, 2015:320).

Menurut Sugiyono (2008:89), analisis data adalah proses mencari dan menyusun secara sistematis data yang diperoleh dari hasil wawancara, catatan lapangan, dan dokumentasi, dengan cara mengorganisasikan data kedalam kategori, menjabarkan ke dalam unit-unit, melakukan sintesa, menyusun ke dalam pola, memilih mana yang penting dan mana yang akan dipelajari, dan membuat kesimpulan sehingga mudah dipahami oleh diri sendiri maupun orang lain. Sedangkan menurut Afifuddin \& Saebani (2012:145) analisis data adalah proses mengatur urutan data, mengorganisasikan ke dalam suatu pola, kategori, dan satuan uraian dasar.

\section{HASIL DAN PEMBAHASAN}

Desa Pangkalan Benteng merupakan sentra produksi Batu Bata di Kabupaten Banyuasin. Menurut Juha sebagai informan mengatakan "industri Batu Bata di desa ini sangat banyak, kalau mau dihitung bingung juga kami berapa banyak 
jumlahnya, mungkin sampai ratusan bisa jadi sampai 400 industri soalnya hampir di setiap tempat di jumpai industri Batu Bata" (Catatan Wawancara Lapangan No. 2, narasumber: 2)

Berdasarkan keterangan Juha bahwa industri Batu Bata di Pangkalan Benteng sangat banyak bisa mencapai lebih kurang 400 industri sama halnya dengan informan Awalin mengatakan "banyak dek, begitu banyaknya sampai tidak tahu jumlah pastinya berapa, apalagi industri ini kan sebagai sumber mata pencaharian" (Catatan wawancara no.4, narasumber: 4).

Menurut ungkapan Awalin industri Batu Bata memang banyak tersebar di desa Pangkalan Benteng karena industri Batu Bata juga sebagai sumber mata pencaharian warga desa Pangkalan Benteng maupun warga di wilayah lain. Hal ini di dukung juga oleh informan yang menjabat sebagai seketaris desa menurut informasi dari Rusli mengatakan "kalau dihitung satu per satu banyak dek, tapi berdasarkan catatan dari kantor ini tercatat sekitar 400, itu diketahui dari kita gotong royong dalam perbaikan jalan, kan setiap industri dikenai biaya tertentu, dari situ kita bisa mencatat jumlah industri Batu Bata yang ada di desa ini. tetapi industri Batu Bata setiap tahunnya bisa berkurang bisa juga makin bertambah tergantung dari perekonomian dan harga jual Batu Bata tersebut" (Catatan wawancara no.1, narasumber: 1).

Menurut ungkapan Rusli bahwa jumlah industri Batu Bata yang tercatat di kantor kepala desa Pangkalan Benteng mencapai sekitar 400 industri hal ini diketahui berdasarkan kegiatan gotong royong masyarakat desa yang mewajibkan setiap industri berkontribusi untuk perbaikan jalan, namun setiap tahunnya industri Batu Bata bisa berubah jumlahnya bisa berkurang dan juga bisa bertambah. Bertambahnya industri Batu Bata ini bisa diakibatkan karena banyak warga yang memilih untuk bekerja di industri dari pada berkebun ataupun bertani. Sama halnya informan Suparno yang merupakan salah satu pemilik industri Batu Bata mengatakan "industri Batu Bata disini banyak karena banyak yang memilih bekerja di industri ini dibandingkan berkebun ataupun bertani, seperti saya sudah 10 tahun lebih mengelolah industri Batu Bata ini karena penghasilan dari industri ini lumayan mungkin itulah banyak yang ingin mengelolah indusri Batu Bata juga" (Catatan wawancara no.7, narasumber: 7).

Dari semua pendapat informan di atas dapat diambil kesimpulan bahwa di desa Pangkalan Benteng terdapat 400 industri Batu Bata dan merupakan pusat penghasil Batu Bata yang cukup dikenal di Kabupaten Banyuasin. Hal ini juga dapat bermanfaat bagi masyarakat desa dalam meningkatkan perekonomian di Desa Pangkalan Benteng.

Berdasarkan hasil pengamatan observasi di Desa Pangkalan Benteng bahwa memang terdapat banyak industri Batu Bata, hampir setiap jalan terlihat industri Batu Bata yang memang industri ini sebagai penunjang perekonomian warga di desa Pangkalan Benteng.

\section{Kerusakan Lingkungan Akibat Industri Batu Bata}

\section{Banyaknya Lubang Bekas Galian}

Berdasarkan hasil observasi yang dilakukan bahwa sepanjang perjalanan di Desa Pangkalan Benteng, terdapat satu hal yang menarik yaitu banyak nya lubang- lubang besar yang menyerupai kolam sehingga genangan air yang terjadi dapat menyebabkan masalah lain selain masalah kerusakan lingkungan.

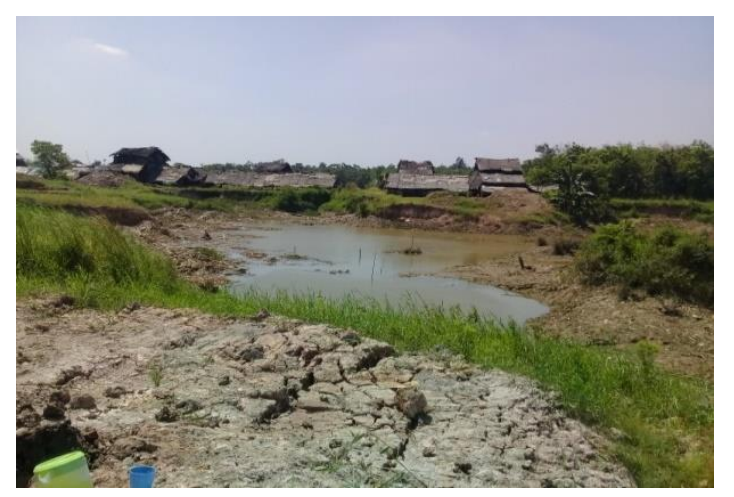

Gambar 1. Lubang bekas galian industri Batu Bata.

(Sumber. Hasil Observasi Lapangan, 2017)

\section{Merusak kualitas dan kuantitas tanah}

Penggalian tanah untuk bahan baku Batu Bata dapat mempengaruhi kemampuan tanah untuk membentuk struktur tanah kembali, sehingga dapat mendorong kemerosotan sumber daya tanah baik kuantitas maupun kualitasnya. Berdasarakan informasi yang diberikan informan Awalin yaitu "tanah ini jadi tidak subur lagi akibat sering digali 
terus kalau mau menanam tanaman juga bingung karena lubang semua dimana-mana kalau tanah disekitar galian lubang terkadang tanaman susah tumbuh juga atau tidak subur" (catatan wawancara no. 4, narasumber: 4).

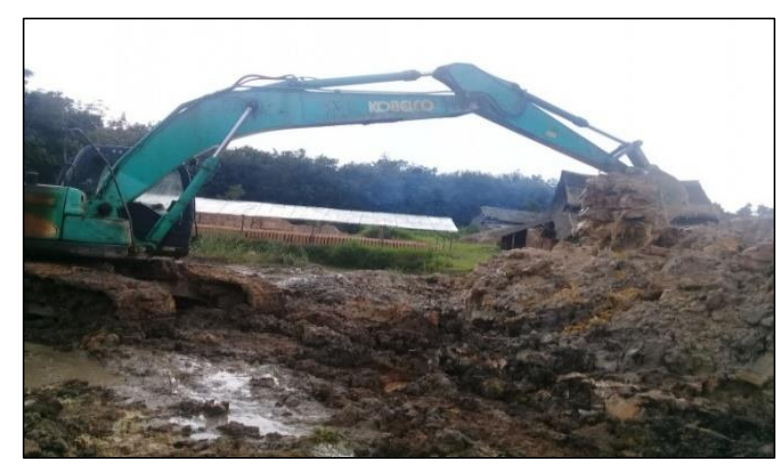

Gambar 2. Menurunnya kualitas dan kuantitas tanah akibat proses penggalian (Sumber. Hasil

Observasi Lapangan, 2017)

\section{Menurunnya Kualitas Air}

Lubang - lubang bekas galian yang dalamnya sekitar 2-5 meter dapat menyebabkan kerusakan pada sumber mata air dan media pengatur daur air menjadi terbatas serta apabila musim penghujan lubang-lubang bekas galian akan menjadi genangan air. Berdasarkan informasi dari informan Nurleni mengatakan "kerusakannya ada, buktinya sekarang menjadi sedikit susah mendapatkan air bersih, jadi kalau untuk air minun kami beli yang air isi ulang, kalau mencuci kami menggunakan air kolam bekas galian ini" (catatan wawancara no. 3, narasumber 3 ).

\section{Pencemaran Udara}

Berdasarkan ungkapan Awalin mengatakan bahwa banyaknya asap disebabkan oleh proses pembakaran untuk pembuatan Batu Bata. Hal ini didukung juga informasi dari informan Rusli yang mengatakan "asap, jadi banyak masyarakat yang mengeluh kalau di waktu pembakaran akan muncul banyak asap, oleh karena itu banyak warga yang terserang penyakit berkaitan dengan udara yang tidak sehat seperti batuk, selain itu udara di sini juga semakin tidak segar karena banyaknya asap yang dihasilkan dari pembakaran di mana-mana."(catatan wawancara no. 1 , narasumber:1).

Menurut ungkapan Rusli mengatakan bahwa masyakat banyak mengeluh akan asap akibat dari proses pembakaran industri Batu Bata yang menyebabkan lingkungan menjadi tidak segar dan juga berdampak pada permasalahan lain salah satunya penyakit gangguan pada pernafasan.

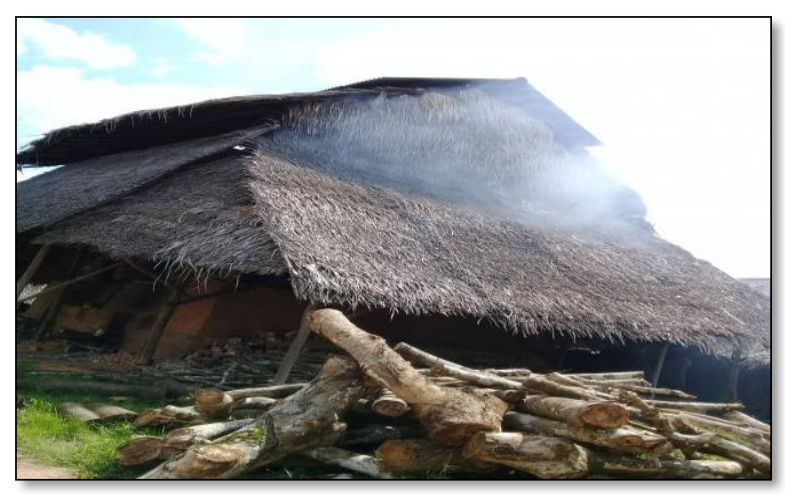

Gambar 3: Asap akibat proses pembakaran Batu Bata (Sumber. Hasil Observasi Lapangan, 2017)

\section{Kerusakan Akses Jalan}

Menurut ungkapan Tamziz mengatakan bahwa jalan yang rusak di akibatkan oleh mobil-mobil truk pengangkut Batu Bata yang mana mobil truk tersebut salah satu akses untuk mengangkut Batu Bata ke luar desa. Hal ini di dukung juga oleh informasi dari informan Jun yang mengatakan "jalan tambah rusak, jadi kalau waktu hujan jalan malah susah di lewati terus kalau musim kemarau debu nya banyak, sudah di benarin jalannya ya tetap rusak lagi karena mobil- truk banyak yang lewat dari truk pengangkut kayu, penggangkut Batu Bata terus mobil alat berat juga sering lewat "(catatan wawancara no. 6 , narasumber: 6 ).

Berdasarkan ungkapan Jun bahwa rusaknya jalan di sebabkan oleh mobil truk pengangkut kayu, mobil truk pengangkut Batu Bata bahkan mobil alat berat juga bisa menyebakan rusaknya jalan akibatnya pada musim hujan jalan menjadi susah dilalui dan pada musim kemarau tanah menjadi berdebu.

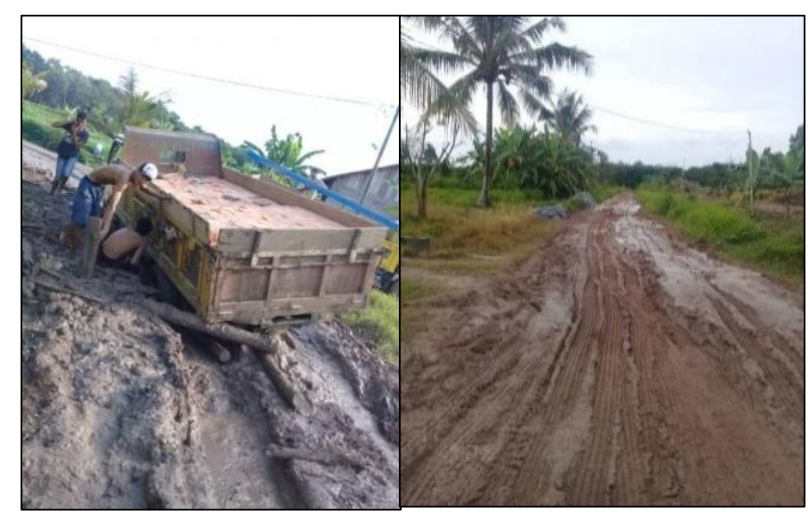

Gambar 4. Kondisi jalan menuju industri Batu Bata (Sumber. Hasil Observasi Lapangan, 2017) 
Berdasarkan hasil wawancara dan observasi, dapat diketahui bahwa Desa Pangkalan Benteng Kecamatan Talang Kelapa Kabupaten Banyuasin telah terjadi kerusakan lingkungan yang disebabkan oleh industri Batu Bata. Diperoleh dari wawancara dengan informan yaitu masyarakat yang bekerja di industri Batu Bata Desa Pangkalan Benteng serta observasi lapangan secara langsung. Data hasil penelitian yang diperoleh terebut selanjutnya di analisis guna menjawab permsalahan dalam penelitian.

Berdasarkan hasil analisis data menunjukan bahwa proses pembuatan Batu Bata dari penggalian bahan baku, pengolahan bahan baku, pencetakan, pembakaran dan pengangkutan atau penjualan dapat menyebabkan kerusakan lingkungan meliputi banyaknya lubang bekas galian, rusaknya kualitas dan kuantitas tanah, menurunnya kualitas air, pencemaran udara dan kerusakan akses jalan. Kerusakan lingkungan yang terdapat di Desa Pangkalan Benteng terjadi karena belum adanya kesadaran dari masyarakat akan pentingnya lingkungan bagi keberlangsungan hidup manusia dan belum berjalanannya peraturan pemerintah mengenail pengolahan lingkungan yang baik dan benar.

Menurut informan kunci Muftiyawati, S.Pd selaku guru mata pelajaran IPS Terpadu (geografi) kelas VIII mengungkapkkan "MTs GUPPI Sukamoro masih menggunakan kurikulum KTSP 2006. Terkait fenomena kerusakan lingkungan salah satu topik permasalahan yang dapat dijadikan sebagai sumber belajar pada standar kompetensi memahami permasalahan sosial terkait dengan pertumbuhan penduduk, kompetensi dasar mendeskripsikan permasalah lingkungan hidup dan upaya penanggulangannya dalam pembangunan berkelanjutan pada materi pembelajaran bentuk kerusakan lingkungan hidup dan faktor penyebabnya" (Catatan wawancara lapangan no.8, narasumber: 8). Berdasarkan keterangan informan kunci bahwa terjadi fenomena kerusakan lingkungan merupakan salah satu topik permasalahan yang dapat dijadikan sebagai sumber pembelajaran yang cocok digunakan di MTs GUPPI Sukamoro yang mana lokasinya berdekatan sehingga siswa mudah dalam memahaminya. Fenomena kerusakan lingkungan ini tertuang pada silabus pelajaran IPS kelas VIII semester satu pada Standar Kompetensi 1. Memahami permasalahan sosial berkaitan dengan pertumbuhan jumlah penduduk. Kompetensi dasar 1.1. mendeskripsikan permasalahan lingkungan hidup dan upaya dalam pembangunan berkelanjutan pada materi pembelajaran bentuk kerusakan lingkungan hidup dan faktor penyebabnya. Sehingga dapat digunakan sebagai sumber belajar di MTs GUPPI Sukamoro sebagai sumber belajar yang baru selain dari buku geografi yang relevan dan artikel-artikel yang tersedia di MTs GUPPI Sukamoro. Selain itu dapat mengenalkan kepada siswa bahwa Desa Pangkalan Benteng merupakan sentra pembuatan Batu Bata di kabupaten Banyuasin dengan memiliki manfaat didalamnya baik manfaat positif dan negatif.

\section{SIMPULAN}

Desa Pangkalan Benteng merupakan salah satu desa yang berada di Kecamatan Talang Kelapa dengan berbagai kegiatan di dalamnya, seperti kegiatan pertanian, perkebunan, usaha dan industri dan lain sebagainya. Usaha dan industri yang berada di Desa Pangkalan Benteng salah satunya yaitu industri Batu Bata. Industri Batu Bata di Desa Pangkalan Benteng jumlahnya mencapai 400 industri. Hal ini membuat Desa Pangkalan Benteng menjadi sentra penghasil Batu Bata yang cukup dikenal di Kabupaten Banyuasin. Industri Batu Bata memberikan pengaruh positif maupun negatif terhadap kondisi lingkungan. Pengaruh positif dari keberadaan industri Batu Bata adalah penyerapan tenaga kerja, sumber mata pencaharian penduduk, dan daya beli masyarakat meningkat. Sedangkan pengaruh negatif dari industri tersebut berpengaruh pada kerusakan lingkungan fisik di sekitar industri Batu Bata yang meliputi banyaknya lubang bekas galian, merusak kualitas dan kuantitas tanah, menurutnya kualitas air, pencemaran udara dan kerusakan akses jalan.

Dengan fenomena kerusakan lingkungan tersebut merupakan contoh nyata dan dengan adanya beberapa kerusakan lingkungan akibat industri Batu Bata di Desa Pangkalan Benteng dapat menggambarkan kerusakan lingkungan yang terjadi di sekitar sehingga dapat dijadikan sebagai sumber belajar IPS (geografi) di MTs GUPPI Sukamoro 
yang kebetulan lokasinya berdekatan sehingga siswa lebih mudah dalam memahami pembelajaran.

\section{DAFTAR PUSTAKA}

Abdullah, Ramli. (2012). Pembelajaran Berbasis Pemanfaatan Sumber Belajar. Fakultas Tarbiyah Ar-Raniry VOL. XII No.2 216-231.

Afifudin dan Beni Ahmad Saebani.(2012). Metodologi Penelitian Kualitatif. Bandung: Pustaka Setia.

Arikunto, Suharsimi. (2010). Prosedur Penelitian :Suatu Pendekatan Praktek. Jakarta: Rineka Cipta.

Arikunto, Suharsimi.(2014). Prosedur Penelitian :Suatu Pendekatan Praktek. Jakarta: Rineka Cipta.
Mudyahardjo, Redja. (2001). Pengantar Pendidikan. Jakarta: PT. RajaGrafindo Persada

Prastowo, Andi. (2012). Pengembangan Sumber Pembelajaran. Yogyakarta: PEDAGOGIA.

Riduwan. (2015). Belajar Mudah Penelitian: Untuk Guru-Karyawan dan Peneliti Pemula. Bandung : Alfabeta

Sugiyono. (2008). Memahami Penelitian Kualitatif. Bandung: Alfabeta.

Sugiyono. (2015). Metode Penelitian Pendidikan Pendidikan Pendekatan Kuantitatif, Kualitatif dan $R \& D$. Bandung: Alfabeta.

Wijayanti, Wikan. (2012). Membuat Genteng dan Batu Bata. Tanggerang Selatan: Tirta Media.

Yunus, Hadi Sabari. (2010). Metodologi Penelitian Wilayah Kontemporer. Yogyakarta: Pustaka Pelajar. 